\title{
FACAS TÁTICAS: NOVAS CONFIGURAÇÕES ERGONÔMICAS PARA ADEQUÁ-LAS À CAÇA E À PRÁTICA MILITAR
}

\section{TACTICAL KNIVES: NEW ERGONOMIC SETUPS FOR ADEQUATING THEM TO HUNT AND MILITARY PRACTICE}

\author{
Weynner Santos ${ }^{1}$, M.Sc. \\ wkbs@cin.ufpe.br e https://orcid.org/0000-0001-7420-8718 \\ Walter Correia, D.Sc. ${ }^{1}$, D.Sc. \\ wfmc10@gmail.com e https://orcid.org/0000-0002-6491-9783
}

${ }^{1}$ Laboratório de Concepção e Análise de Artefatos Inteligentes/CAC, UFPE, Recife, Brasil

ergonomia, facas táticas, design de produto, arma branca

Este artigo apresenta uma investigação revisada das características estéticas e funcionais das facas táticas, isso é, aquelas projetadas estrategicamente para operações de risco, como nas atividades de policiais, bombeiros, socorristas, campistas, mergulhadores ou caçadores. Estes produtos tiveram seu desenvolvimento minimamente registrado na ciência formal, sendo que o conhecimento sobre o design e sobre a avaliação de facas táticas se deu quase exclusivamente em meio artesanal ou industrial. As empresas não revelam seus processos de design, e os artesãos que o fazem, não têm qualquer comprovação científica quanto aos resultados que alcançaram no decorrer das décadas: foi um processo de tentativa e erro, até se chegar a níveis de qualidade adequados aos usuários. Neste projeto, investigam-se possíveis diretrizes formais da ergonomia e da usabilidade de facas táticas que possam ser testadas na produção desses produtos, buscando registrar cientificamente tal linha de pesquisa e sua relevância à indústria militar. Desde à época da realização deste projeto de conclusão de curso, em 2012, até o ano corrente, não havia produções acadêmicas que definissem, classificassem ou testassem facas táticas, sob a visão de qualquer disciplina de análise de qualidade.

ergonomics, tactical knives, product design, cold weapon

This paper presents a reviewed investigation of the aesthetical and functional features of tactical knives, that is, those strategically designed for risk operations, as in the activities of policemen, fire-fighters, rescuers, campers, divers or hunters. These products had their development minimally registered in formal science, as the knowledge about the design and about the evaluation of tactical knives is almost exclusively in the handcraft and industry environments. Companies do not reveal their design processes, and the craftsmen who do it, do not have any way for scientific proof to the achieved results from decades of work: it was a process of trials and mistakes, until they reached quality levels adequate to users. In this project, there is an investigation of possible formal guidelines of ergonomics and usability of tactical knives which could be tested for production of such itens in the future, searching to scientifically register this research line and its relevance to military industry. Since the time of the realization of this course completion project, in 2012, until the current year, there was no academic production that could have defined, classified or tried tactical knives, under the vision of any quality analysis discipline. 


\section{Introdução}

O desenvolvimento industrial tem objetivado principalmente o avanço tecnológico na fabricação de produtos. Os artefatos são produzidos tanto sob a égide de padrões técnicos de qualidade quanto de questões no âmbito social, aumentando performance e aceitação do produto no mercado por parte de seus usuários. Para CUSHMAN \& ROSENBERG (1991), à medida que um produto é baseado numa nova tecnologia, o risco de falhas em sua implementação é sempre maior. Na indústria militar não é diferente, e ela ainda sofre com problemas oriundos de um contexto de produção muito cartesiano: não há uma intervenção criativa em suas metodologias, predominadas pelo pensamento das ciências exatas.

As facas militares compartilham parcialmente deste problema: grande parte destes produtos segue estritamente valores funcionais, e outra parte tende a ser altamente voltada à estética. Não existe equilíbrio metodológico, pois, mesmo quando uma faca alcança altos níveis de qualidade em Design, normalmente foi através de um processo decisório não mapeado, empírico, pessoal. Estas ferramentas carecem, portanto, de maior adequação aos seus usuários; e de uma maneira menos inconsciente de produção: é sobre alcançar mais ergonomia e estética de forma consciente, planejada, científica.

Através do uso de guias e diretrizes de Ergonomia e Usabilidade propostos por autores consagrados (CUSHMAN \& ROSENBERG, 1991; NIELSEN, 1994; JORDAN, 2002), e pelo mapeamento de um conjunto de atividades (LEONTIEV, 1978; VYGOTSKY, 1978; ENGESTRÖM, 1987) no manuseio de facas táticas, são propostas neste artigo boas práticas ergonômicas ao projeto desses artefatos, listando tópicos sobre forma, cor e funcionalidade enquanto armas brancas para caça ou uso militar, e enquanto ferramentas de auxílio à sobrevivência em ambientes hostis.

\section{Metodologia}

A realização deste estudo foi permeada por três etapas metodologicamente distintas (Figura 1): primeiro, uma revisão assistemática de literatura permitiu o levantamento de dados relevantes sobre a produção de facas táticas por artesãos e empresas internacionais. Não havia, até a redação deste documento, nenhuma produção acadêmica que trabalhasse especificamente com este tema, o que dificultava a realização de uma revisão sistemática. Nesta revisão bibliográfica, foram achadas informações sobre: 1) história, conceito e definição das armas brancas; 2) tipos e partes de uma faca; 3) perfis e moagens mais usados na fabricação de facas, 4) diretrizes de ergonomia e usabilidade adequadas ao estudo das facas táticas.

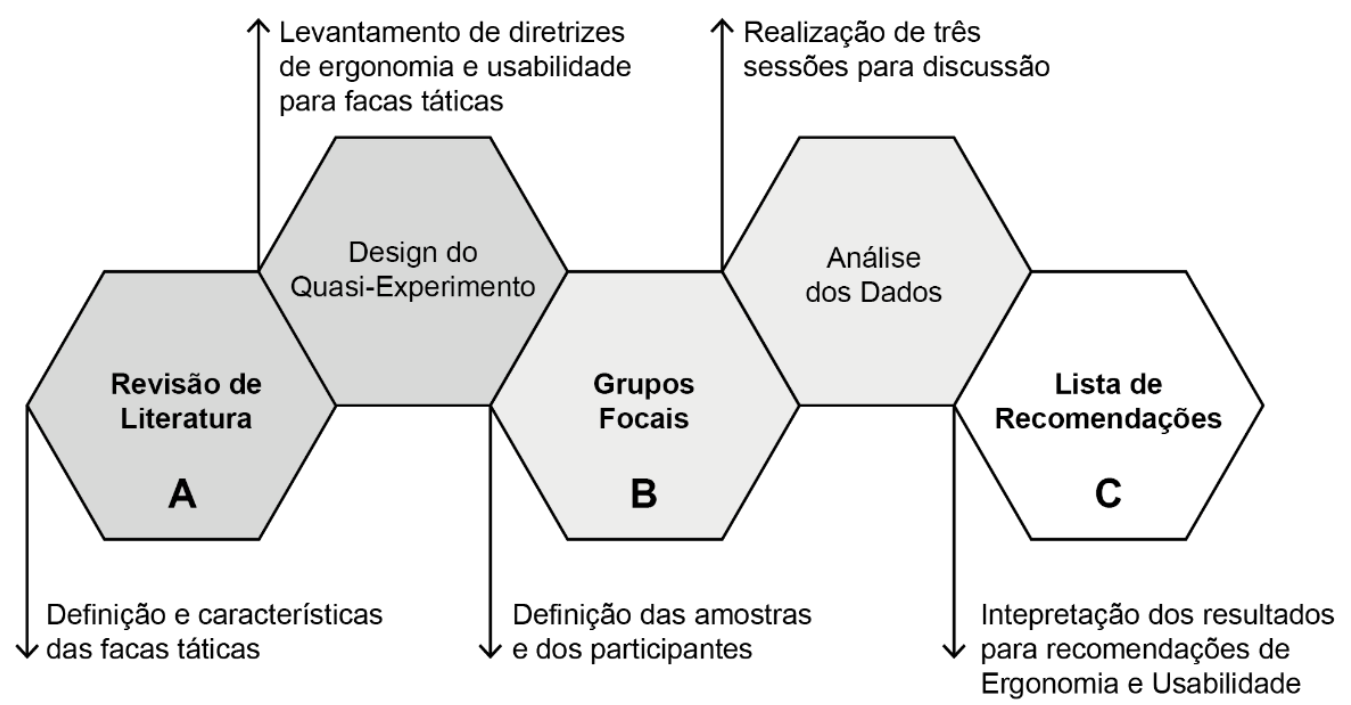

Figura 1. Mapa metodológico da pesquisa (produção dos autores). 
Segundo, foi realizada uma pesquisa de campo com três sessões de Grupo Focal (MARTIN \& HANINGTON, 2012) com estudantes de combate tático e seu instrutor, de uma academia certificada de artes marciais no Estado de Pernambuco. Esta etapa foi crucial para mapear pontos de dor, queixas, inconsistências de uso e falhas de manuseio por parte desses usuários com modelos de faca considerados táticos. Para isso, recorreu-se à tríade de interrelações proposta pela Teoria da Atividade (ENGESTRÖM, 1987; 1993), que mapeia e caracteriza as tarefas e os níveis de operação para as realizar.

Nessas sessões, participaram alguns estudantes da academia, todos agentes policiais, militares, bombeiros e socorristas, mais o instrutor. Durante a realização desses encontros, optou-se pelo uso do Protocolo Pensar Alto (MARTIN \& HANINGTON, 2012), para que os membros pudessem externar suas opiniões sobre facas e simulacros enquanto manuseavam os produtos. As discussões ocorreram antes da aplicação dos questionários, já que estes serviram para registro das opiniões desses participantes, de uma forma já nivelada e consciente. Finalmente, a construção de uma lista de recomendações ergonômicas e de usabilidade para o design de facas táticas.

\section{Classificação das Armas Brancas}

Desde os primórdios, o ser humano tem alterado a forma como interage com o ambiente ao seu redor, adaptando-se e evoluindo não apenas em nível genético, mas desenvolvendo todo um panteão de roupas, ferramentas e acessórios para auxiliá-lo nas mais diversas atividades de seu cotidiano. Foi nessa mesma época que a primeira pedra foi usada como instrumento de corte, sugerindo-nos o surgimento de um dos primeiros exemplares de armas brancas. Quando se avalia a evolução histórica das armas brancas, elas podem ser divididas em três períodos: anterior à Idade Média; Idade Média ao Moderno; e o Contemporâneo (DORLING KINDERSLEY, 2012).

Mas foi apenas após a Segunda Guerra que a maior parte das armas brancas se tornaram irrelevantes na indumentária militar, sendo mais aproveitadas por usuários civis em momentos de lazer, defesa pessoal e para auxílio doméstico. As facas, por outro lado, se mantiveram relevantes, pois em áreas fechadas, como trincheiras, vielas e interior de edifícios, ainda provavam ser eficientes, especialmente quando a munição faltava.

Atualmente, as armas brancas são classificadas conforme seu modo de operação e o tipo de dano que causam. Há três tipos primários: as cortantes, as perfurantes e as contundentes, sendo a primeira capaz de lacerar; a segunda de gerar furos; e a terceira de fraturar ou obliterar objetos. A partir da união de cada um desses três conceitos que surgem as diversas variações de armas brancas, sendo esta titulação adotada internacionalmente. É possível ainda separar as armas brancas entre as de contato (corpo-a-corpo) as de arremesso (lançáveis) e as projéteis (atiráveis com mecanismo). Quando uma arma é capaz de gerar mais de uma forma de dano, ela é enquadrada numa das intersecções do modelo na Figura 2.

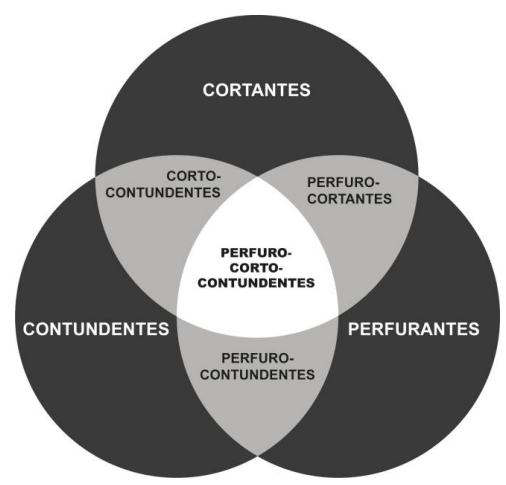

Figura 2. Classificação das armas brancas (PIMENTA, 2011; adaptação dos autores). 
Dentro desta diversificação, porém, não existe uma total clareza acerca do quanto cada uma das armas classificadas faz parte de um grupo ou de outro, uma vez que uma arma pode, ainda que de maneira secundária, efetuar dano de um tipo diferente da que foi caracterizada no modelo. São alguns exemplos de armas brancas em suas respectivas classificações (Tabela 1):

\begin{tabular}{|c|c|c|}
\hline Tipo & Descrição & Exemplos \\
\hline Cortantes & $\begin{array}{l}\text { São todas aquelas capazes de causar danos em forma de } \\
\text { lacerações e rasgos de contorno regular ou não. }\end{array}$ & Navalhas e giletes. \\
\hline Perfurantes & $\begin{array}{l}\text { Possuem pontas agudas capazes de atravessar superfícies } \\
\text { num único e retilíneo vetor de direção. }\end{array}$ & $\begin{array}{l}\text { Agulhas, chaves de fenda, floretes, } \\
\text { garfos, estacas e flechas. }\end{array}$ \\
\hline Contundentes & $\begin{array}{l}\text { Geram danos por impacto, através de pancadas fortes que } \\
\text { dependem do peso exercido por seus modelos, causando } \\
\text { amassos e fraturas. }\end{array}$ & $\begin{array}{l}\text { Martelos, bastões, porretes e } \\
\text { soqueiras. }\end{array}$ \\
\hline Cortocontundentes & $\begin{array}{l}\text { Conseguem causar dano tanto através da laceração quanto } \\
\text { do impacto. Este segundo é crucial para o aumento da } \\
\text { capacidade de corte da classe. }\end{array}$ & Guilhotinas e machados. \\
\hline Perfurocortantes & $\begin{array}{l}\text { Possuem tanto poder de furo quanto de corte, pois seus } \\
\text { formatos agudos e a presença de pelo menos um gume lhes } \\
\text { dão tal característica. Apesar de a maioria das pessoas leigas } \\
\text { considerarem a faca como uma arma branca cortante, na } \\
\text { verdade, ela se enquadra melhor nesta classificação. }\end{array}$ & Adagas e punhais. \\
\hline Perfurocontundentes & $\begin{array}{l}\text { Podem efetuar perfurações muito mais fortes, pois dependem } \\
\text { da força aplicada e do centro de massa do objeto manuseado, } \\
\text { sendo que seus furos, se comparados aos das armas } \\
\text { perfurantes, são muito mais poderosos, pois à medida que } \\
\text { furam, separam ou esmagam a região do corpo em contato. }\end{array}$ & $\begin{array}{l}\text { Picareta, arpão, alguns tipos de } \\
\text { lança, flechas e maças com } \\
\text { espinhos. }\end{array}$ \\
\hline Perfurocortocontundentes & $\begin{array}{l}\text { Estas geralmente são as armas brancas com melhor } \\
\text { performance, pelo equilibrio entre poder de dano, peso, } \\
\text { velocidade e forma de manuseio. São capazes de perfurar, } \\
\text { cortar e fraturar ao mesmo tempo ou de uma dessas ações } \\
\text { por vez. Dependendo do tamanho da faca e da força que se } \\
\text { aplica sobre ela, o produto passa a ser parte desta categoria. }\end{array}$ & $\begin{array}{l}\text { Espadas de grande porte como } \\
\text { montantes; catanas, cimitarras, } \\
\text { lanças orientais e as machadinhas } \\
\text { japonesas com esferas e correntes. }\end{array}$ \\
\hline
\end{tabular}

Tabela 1. Exemplos das diversas classes de armas brancas (PIMENTA, 2011; DORLING KINDERSLEY, 2012; adaptação dos autores).

Não é apenas difícil caracterizar cada um dos modelos de armas brancas, como também alguns modelos fogem esteticamente de uma noção superficial de classificação, sendo que para um usuário, é difícil entender a diversidade dessas ferramentas e como escolher a que melhor se adequa ao contexto de sua necessidade.

\section{Anatomia de uma Faca}

A faca ainda é uma das mais complexas armas brancas que existem, dado o número de componentes que a caracterizam, mesmo que a maioria passe despercebido, pois grande parte das pessoas imaginam que uma faca é simplesmente composta por uma lâmina e uma empunhadura. Um projetista necessita ter em mente cada uma dessas partes (Figura 3) da faca de modo a conseguirem manipular conscientemente cada uma delas, obtendo assim modelos variados. Grande parte desses componentes não é obrigatório ou essencial para se obter uma faca (Tabela 2).
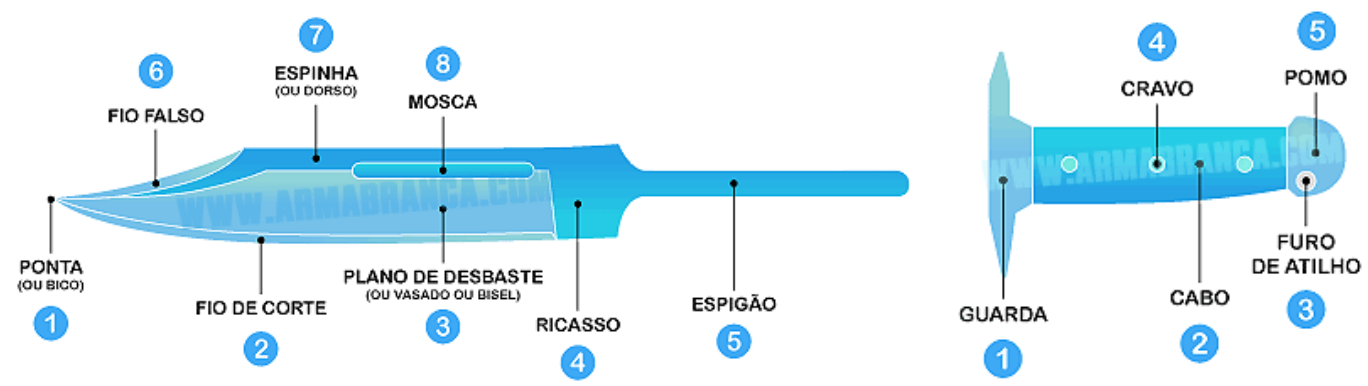

Figura 3. Partes de uma faca: lâmina à esquerda e empunhadura ou cabo à direita (ARMA BRANCA, 2009). 


\begin{tabular}{|c|c|}
\hline $\begin{array}{l}\text { Partes da } \\
\text { lâmina }\end{array}$ & Descrição \\
\hline $\begin{array}{l}1-\text { Ponta ou } \\
\text { bico }\end{array}$ & $\begin{array}{l}\text { Extremidade mais aguda da secção cortante da lâmina, a partir da qual se realiza o dano de perfuração na } \\
\text { superfície com que entra em contato. }\end{array}$ \\
\hline 2 - Fio de corte & $\begin{array}{l}\text { Responsável por realizar a laceração. De acordo com o perfil e a moagem da lâmina, pode-se obter diversos } \\
\text { níveis de eficácia para as muitas funções que uma faca pode desempenhar. }\end{array}$ \\
\hline 3 - Bisel & $\begin{array}{l}\text { Estende-se do dorso até o fio, sendo responsável por espessar a lâmina de forma que achata gradativamente } \\
\text { em direção ao fio de corte. }\end{array}$ \\
\hline 4 - Ricasso & $\begin{array}{l}\text { Serve como uma primeira guarda antes da existente no cabo, mantendo a espessura original da chapa e } \\
\text { trazendo o centro de gravidade para junto ao cabo. }\end{array}$ \\
\hline 5 - Espigão & $\begin{array}{l}\text { Atua como união entre a lâmina e o cabo. Hoje em dia não é muito utilizado, pois a grande maioria das facas } \\
\text { são feitas em monoblocos, onde a lâmina possui uma extensão interior ao cabo de dimensões iguais ou } \\
\text { semelhantes a ele. }\end{array}$ \\
\hline $6-$ Fio falso & $\begin{array}{l}\text { Resultado de um segundo desbaste que não apresenta fio verdadeiro, servindo apenas para auxiliar na } \\
\text { penetração. Algumas facas empregam mais de um fio verdadeiro às lâminas, sendo o fio falso, portanto, um } \\
\text { componente opcional. }\end{array}$ \\
\hline $\begin{array}{l}7 \text { - Espinha ou } \\
\text { dorso }\end{array}$ & $\begin{array}{l}\text { Responsável por manter a espessura original e servir como origem para o bisel, podendo ser encontrada numa } \\
\text { extremidade lateral ou na linha central de uma faca de dois fios. }\end{array}$ \\
\hline 8-Mosca & $\begin{array}{l}\text { Diminuir o peso da faca (já que retira massa do metal). Muitos fabricantes afirmam que as moscas facilitam a } \\
\text { retirada da lâmina de dentro de objetos, pois sua reentrância impede a geração de vácuo, mas não há } \\
\text { evidências científicas que comprovem esse fenômeno. }\end{array}$ \\
\hline $\begin{array}{l}\text { Partes da } \\
\text { empunhadura }\end{array}$ & Descrição \\
\hline 1 - Guarda & $\begin{array}{l}\text { Separa o cabo e a lâmina, recebendo este nome porque previne que a mão ou os dedos escorreguem e entrem } \\
\text { em contato com o fio, além de conferir mais força pelo contato de pressão contra ela. }\end{array}$ \\
\hline $2-$ Cabo & $\begin{array}{l}\text { A empunhadura é o maior alvo da Ergonomia, pois é a partir do contato com ela que se exerce todo o uso do } \\
\text { equipamento. }\end{array}$ \\
\hline $\begin{array}{l}3-\text { Furo de } \\
\text { atilho }\end{array}$ & $\begin{array}{l}\text { Serve para a passagem de uma corrente ou atilho para prender a faca em alguma parte do corpo do usuário (no } \\
\text { cinturão ou colete, por exemplo), facilitando que seja carregada sem uma bainha fixa. }\end{array}$ \\
\hline $4-$ Cravo & $\begin{array}{l}\text { Este taco metálico serve como unificador entre as duas metades longitudinais do cabo e o espigão. Mas assim } \\
\text { como o espigão vem sendo substituído, os cravos também vêm perdendo espaço para o uso de dentes e cabos } \\
\text { vazados não seccionados, isso quando algumas empresas não optam por utilizar parafusos propriamente ditos } \\
\text { para fechar os cabos. }\end{array}$ \\
\hline 5- Pomo & $\begin{array}{l}\text { Segura o espigão na parte exterior do cabo, além de não permitir a fuga do cabo pela parte anterior da mão. Em } \\
\text { algumas facas passa ter função de dano: passa a se chamar "quebra-crânio", por atuar como contundente não- } \\
\text { letal. }\end{array}$ \\
\hline
\end{tabular}

Tabela 2. Partes da lâmina e do cabo de uma faca e suas funções (ARMA BRANCA, 2009).

Além de todos os componentes descritos acima, uma faca quando projetada é feita para se adequar a um uso específico e, por este motivo, possui um perfil e um tipo de moagem diferente. O perfil indica qual será a forma geral da faca - a silhueta - e a moagem, a maneira como o metal será desbastado do bisel ao fio, conferindo um efeito singular.

\subsection{Perfis de uma Lâmina}

Cada perfil apresenta uma configuração diferente quanto à posição e geometria dos componentes da lâmina, podendo alcançar variações diversas (Figura 4) de acordo com o necessário para o uso correto (Tabela 3). 


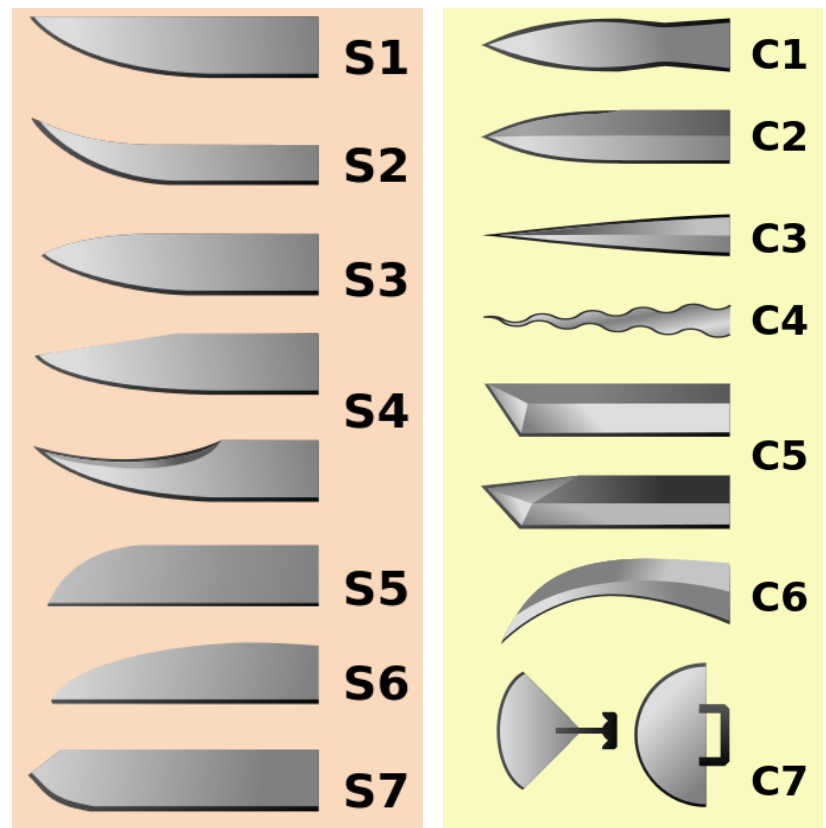

Figura 4. Diversos perfis de lâmina: lâminas de fio simples (S) à esquerda e de fio composto (C) à direita (WARLOEG, 2013).

\begin{tabular}{|c|c|}
\hline $\begin{array}{l}\text { Lâminas de fio } \\
\text { simples (S) }\end{array}$ & Características \\
\hline S1. Comum & $\begin{array}{l}\text { Uma faca com a parte anterior pesada. É a lâmina mais comum, contando com um fio curvado mais próximo ao } \\
\text { bico e um dorso reto. Possui bons níveis de arrasto na perfuração. }\end{array}$ \\
\hline $\begin{array}{l}\text { S2. Ponto de } \\
\text { arrasto }\end{array}$ & $\begin{array}{l}\text { Indicada para retirar a pele de animais, pois a ponta tem um leve alavanco para cima, aumentando a área de } \\
\text { corte, mas diminuindo o poder de perfuração. É mais indicada para lacerações regulares. }\end{array}$ \\
\hline $\begin{array}{l}\text { S3. Ponto de } \\
\text { queda }\end{array}$ & $\begin{array}{l}\text { Com uma convexidade na espinha, facilita uma laceração suave e precisa, mas não é muito indicada para } \\
\text { perfurar. São lâminas fortes e portáteis. }\end{array}$ \\
\hline $\begin{array}{l}\text { S4. Ponto de } \\
\text { clipe }\end{array}$ & $\begin{array}{l}\text { Com grampeado reto ou côncavo na parte de cima da espinha, esta faca possui um fio falso que facilita a } \\
\text { perfuração, a coleta e a seleção de materiais com a ponta. }\end{array}$ \\
\hline $\begin{array}{l}\text { S5. Pé-de- } \\
\text { ovelha }\end{array}$ & $\begin{array}{l}\text { Inicialmente projetada para aparar as patas das ovelhas, esta lâmina é reta e seu dorso se curva em direção ao } \\
\text { fio pouco antes da ponta. Esse dorso reto permite que os dedos sejam colocados sobre ele, aumentando a } \\
\text { precisão e a suavidade do corte. }\end{array}$ \\
\hline S6. Wharncliffe & $\begin{array}{l}\text { Semelhante ao modelo pé-de-ovelha, esta faca possui espinha ainda mais circular, além de uma convexidade, } \\
\text { da ponta ao fim do ricasso. Elas eram muito utilizadas por marinheiros, pois dificultava a ocorrência de } \\
\text { acidentes durante o movimento das embarcações. }\end{array}$ \\
\hline $\begin{array}{l}\text { S7. Ponto de } \\
\text { velocidade }\end{array}$ & $\begin{array}{l}\text { Projetada inicialmente para a castração de animais, esta faca possui um único e retilíneo fio de corte que se } \\
\text { curva abruptamente na ponta, tendo continuidade interrompida por sua espinha, que quebra e retorna ao cabo } \\
\text { também em linha reta. Não é uma faca de uso comum, pois quase não possui poder de perfuração. }\end{array}$ \\
\hline $\begin{array}{l}\text { Lâminas de fio } \\
\text { composto (C) }\end{array}$ & Características \\
\hline C1. Folha & $\begin{array}{l}\text { Possui uma cintura que forma uma espécie de barriga em direção à ponta, o que a torna ideal para o } \\
\text { arremesso, pois seu peso é deslocado em direção ao bico. }\end{array}$ \\
\hline $\begin{array}{l}\text { C2. Ponta de } \\
\text { lança }\end{array}$ & $\begin{array}{l}\text { Possui espinha centralizada no eixo y, tornando a faca completamente simétrica. É uma das lâminas mais fortes } \\
\text { e equilibradas que existe, sendo a que menos sofre estresse durante perfurações, pois a dissipação de energia } \\
\text { é igual para toda a faca. Contudo, não é que melhor lacera ou perfura. }\end{array}$ \\
\hline $\begin{array}{l}\text { C3. Ponta de } \\
\text { agulha }\end{array}$ & $\begin{array}{l}\text { Ao reduzir a largura da lâmina, ela se torna uma faca feita especialmente para a perfuração. Apesar disso, é a } \\
\text { mais frágil, principalmente se em contato com materiais muito duros. Também é muito útil para cortes em áreas } \\
\text { de difícil acesso. }\end{array}$ \\
\hline $\begin{array}{l}\text { C4. Kris (lâmina } \\
\text { de fogo) }\end{array}$ & $\begin{array}{l}\text { Essa lâmina possui equilíbrio semelhante à ponta de lança, mas não é facilmente manuseada, pois nem perfura } \\
\text { nem corta regularmente. Seu poder de corte depende do material em que é fabricada e da proficiência de seu } \\
\text { usuário. }\end{array}$ \\
\hline C5. Tanto & $\begin{array}{l}\text { De origem japonesa, as lâminas tanto são encontradas nas espadas catana e wakizashi, possuindo excelente } \\
\text { capacidade para estropia de sólidos e altos níveis de perfuração. Este equilíbrio depende da espinha semi } \\
\text { central e do alavanco suave que esta faca possui (ele pode ser reto ou curvo) em sua ponta. Além disso, a } \\
\text { curvatura final da lâmina e a moagem também interferem em sua qualidade. }\end{array}$ \\
\hline $\begin{array}{l}\text { C6. Bico de } \\
\text { falcão }\end{array}$ & $\begin{array}{l}\text { Amolada pela borda interior, esta faca é ideal para rasgos (cortes rápidos e irregulares com pouca superfície de } \\
\text { contato) mesmo que a lâmina não consiga entrar com facilidade ou completamente numa superfície. }\end{array}$ \\
\hline C7. Ulu & $\begin{array}{l}\text { Esta lâmina circular não possui ponta e foi desenvolvida pelos povos indígenas canadenses e do ártico para a } \\
\text { raspagem de peles, couro e algumas madeiras. }\end{array}$ \\
\hline
\end{tabular}

Tabela 3. Alguns perfis de lâmina e suas características (LANSKY SHARPENERS, 2013). 
Essas silhuetas distintas permitem que uma faca adquira funções diversas, ainda que todas pudessem ser usadas para combate. Elas também carregam bastantes conotações históricas e estilísticas, já que trazem em seu design a influência de povos de diversas épocas.

\subsection{Tipos de Moagem de uma Lâmina}

A moagem de uma lâmina amplia ou reduz características específicas de cada faca (Figura 5). À medida que a massa do metal é retirada, um efeito específico vai sendo conferido às lâminas, que conseguem cortar, perfurar, descascar, raspar, arrancar ou adquirir outro efeito, individual ou conjunto.
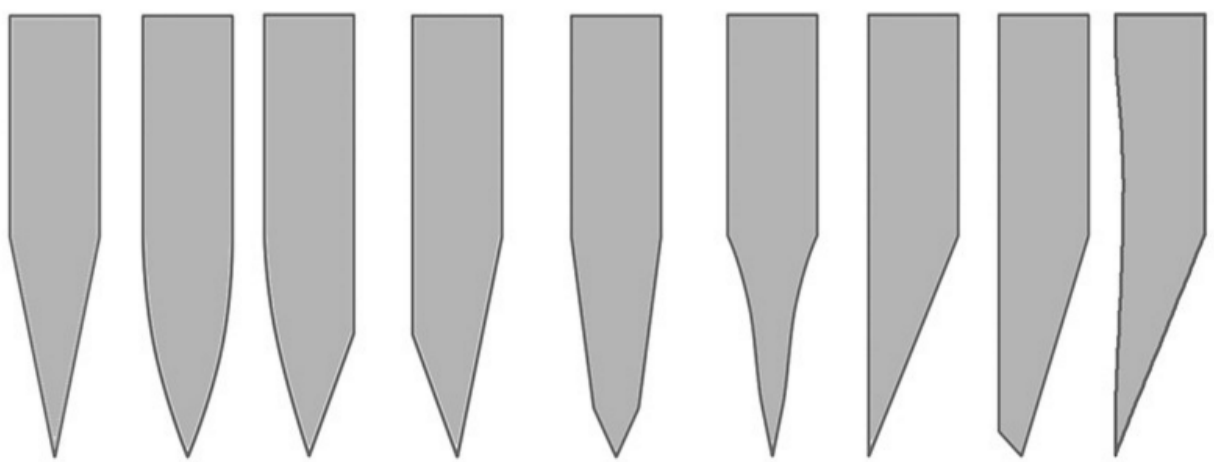

Figura 5. Tipos Diferentes de Moagem para uma Lâmina (Z KNIVES, 2005).

\begin{tabular}{|c|c|}
\hline Chata & $\begin{array}{l}\text { É o tipo mais simples, tem seu bisel a partir da metade longitudinal da faca até o fio. Corta com facilidade, } \\
\text { mas tem baixa durabilidade, induzindo a um tempo de arrasto maior e requerendo restaurações num } \\
\text { intervalo de tempo menor se comparado às outras técnicas. }\end{array}$ \\
\hline Convexa & $\begin{array}{l}\text { É a moagem que possui maior durabilidade, pois a angulação da curva de seu bisel a torna extremamente } \\
\text { equilibrada quanto à dissipação de energia. Permite lacerações regulares graças à suavidade na transição } \\
\text { de linhas do bisel. }\end{array}$ \\
\hline $\begin{array}{l}\text { Assimétrica (ou } \\
\text { Semi convexa) }\end{array}$ & $\begin{array}{l}\text { Pouco usual, este tipo de lâmina combina a durabilidade de lâminas convexas com a facilidade de } \\
\text { amolação das lâminas chatas. Mais durabilidade e mais poder corte. }\end{array}$ \\
\hline Assimétrica chata & $\begin{array}{l}\text { Possui um bisel com ângulos desalinhados propositalmente de ambos os lados, o que confere maior } \\
\text { durabilidade e menor poder de corte. }\end{array}$ \\
\hline $\begin{array}{l}\text { Composta (ou } \\
\text { Bisel duplo) }\end{array}$ & $\begin{array}{l}\text { Seu bisel começa da mesma maneira que a de uma lâmina chata, mas muda para um ângulo externo mais } \\
\text { aberto próximo do fio. Isso confere maior durabilidade e menos poder de corte às lâminas, sendo uma boa } \\
\text { alternativa para aços mais maleáveis ou frágeis. }\end{array}$ \\
\hline Escavada & $\begin{array}{l}\text { É um dos processos que confere maior poder de corte, pelo fato da lâmina se tornar muito fina e ainda } \\
\text { conseguir permanecer suave, devido à concavidade que possui. É a lâmina que tem menor durabilidade do } \\
\text { fio, e gera maior sensação de arrasto devido à circunferência da transição entre o fio e o bisel. }\end{array}$ \\
\hline Cinzelada & $\begin{array}{l}\text { E a lâmina mais afiada e, consequentemente, com maior poder de corte. Ela possui um de seus lados } \\
\text { angulares totalmente retilíneos enquanto o outro apresenta um bisel que afina em direção ao fio e à ponta. }\end{array}$ \\
\hline $\begin{array}{l}\text { Cinzelada com } \\
\text { bisel anterior }\end{array}$ & $\begin{array}{l}\text { Esta variação da lâmina com cinzel possui um minúsculo chanfro de } 3 \text { a } 5 \text { graus na parte anterior pra } \\
\text { reduzir um pouco do poder de corte em prol de uma maior durabilidade do fio. }\end{array}$ \\
\hline $\begin{array}{l}\text { Cinzelada com } \\
\text { urasuki }\end{array}$ & $\begin{array}{l}\text { Tradicional de algumas facas de fio simples da culinária japonesa, ela apresenta um bisel de um dos lados } \\
\text { em direção ao fio e uma concavidade no decorrer da outra face, para reduzir o arrasto durante o corte, } \\
\text { tornando-o mais suave e regular. }\end{array}$ \\
\hline
\end{tabular}

Tabela 4. Diferentes tipos de moagens de uma faca (Z KNIVES, 2005).

A Tabela 4 acima descreve, de cima para baixo, as características de cada tipo de moagem de uma lâmina, conforme apresentadas na Figura 5, da esquerda para a direita. É possível entender que uma boa faca não é aquela que lacera mais ou melhor, mas a mais equilibrada quanto aos diversos fatores de eficiência de uma faca: poder de corte, de perfuração, durabilidade do fio, peso do produto na mão, conforto do manuseio (do cabo) e tempo de arrasto (o tempo que a lâmina precisa ser arrastada sobre uma superfície para cortar eficientemente). Assim, uma faca pode cortar muito profundamente, mas precisa ser arrastada mais devagar sobre um sólido. Outras, cortam rápido e profundamente, mas perdem seu fio muito facilmente. 


\section{Diretrizes Ergonômicas e de Usabilidade para Facas Táticas}

Enquanto a ergonomia avalia questões mais tangíveis do produto, a usabilidade avalia as relações exercidas entre ele e o usuário para a realização das atividades. JORDAN (2002, p. 8) explica que "projetar pela usabilidade significa projetar para aqueles que irão usar o produto em questão. Portanto, é vital entender quem são os usuários do produto e suas características". Nesse caso, não existe produto perfeito, existem apenas aqueles que equilibram melhor o fator humano e o fator mecânico. A ergonomia e usabilidade fornecem algumas diretrizes parar criar um artefato dentro de níveis aceitáveis de interação. Um produto bem projetado precisa ser seguro, eficiente, satisfatório, durável, adequado ao uso e ter boa aparência (DREYFUSS, 1967; WILSON, 1983; apud CUSHMAN \& ROSENBERG, 1991). No caso do projeto de facas, deve-se considerar principalmente os fatores de risco: o que pode levar os usuários de tais produtos a se ferirem ou causarem danos irreversíveis. A partir destas considerações, pode-se formular as seguintes bases de avaliação (Tabela 5):

\begin{tabular}{|l|l|}
\hline Tamanho e peso & $\begin{array}{l}\text { O comprimento da lâmina não deve ultrapassar } 16 \mathrm{~cm} \text { e o do cabo não deve ser inferior a } 9 \mathrm{~cm} \text { nem } \\
\text { ultrapassar os 15. A largura de base da lâmina (área próxima ao cabo) não deve ultrapassar os } 5 \mathrm{~cm} \text { e a do } \\
\text { cabo deve estar entre os } 2,8 \text { e } 4 \mathrm{~cm} \text {. A espessura da lâmina deve estar situada entre 0,1 e 0,4 cm. O peso } \\
\text { total do artefato deve estar situado entre } 100 \text { e } 400 \mathrm{~g} .\end{array}$ \\
\hline Formato & $\begin{array}{l}\text { O cabo das facas deve ter formato-base cilíndrico ou tetraédrico regular. O formato da lâmina varia de acordo } \\
\text { com o uso pretendido à faca. }\end{array}$ \\
\hline $\begin{array}{l}\text { Encaixe nas } \\
\text { mãos }\end{array}$ & $\begin{array}{l}\text { Facas precisam ser seguradas numa pega do tipo força (Figura 6), onde toda a superfície interna dos cinco } \\
\text { dedos e a palma tocam o cabo do produto, segurando-o com firmeza. }\end{array}$ \\
\hline $\begin{array}{l}\text { Movimento no } \\
\text { manuseio }\end{array}$ & $\begin{array}{l}\text { Há três movimentos básicos de manuseio das facas para geraça de dano: perfuração (com a ponta da } \\
\text { lâmina), corte (com o deslize do fio) e em alguns modelos, contusão (extremidade do cabo com quebra- } \\
\text { crânio). }\end{array}$ \\
\hline Cores e texturas & $\begin{array}{l}\text { São preferíveis as cores foscas, texturas lisas para a lâmina e ásperas para o cabo, a fim de propiciar a rápida } \\
\text { identificação de cada componente, de evitar o deslize das mãos, mas sem refletir a luz. }\end{array}$ \\
\hline $\begin{array}{l}\text { Quantidade de } \\
\text { componentes }\end{array}$ & $\begin{array}{l}\text { Preferencialmente, recorrer aos modelos do tipo monobloco e evitar o uso de cravos. Idealmente, uma faca } \\
\text { contemporânea não precisa de mais de três componentes básicos (lâmina, cabo e revestimento do cabo, } \\
\text { quando houver). }\end{array}$ \\
\hline Resistência & $\begin{array}{l}\text { Alta resistência ao impacto, à tração, às variações de temperatura, ao desgaste e à oxidação. É preferível que } \\
\text { a faca seja um mau-condutor elétrico e térmico, e tenha baixa ou nenhuma flexibilidade para maximizar o } \\
\text { dano. }\end{array}$ \\
\hline
\end{tabular}

Tabela 5. Diretrizes de ergonomia e usabilidade para um produto manual portátil (CUSHMAN \& ROSENBERG, 1991, p. 51; adaptação dos autores).

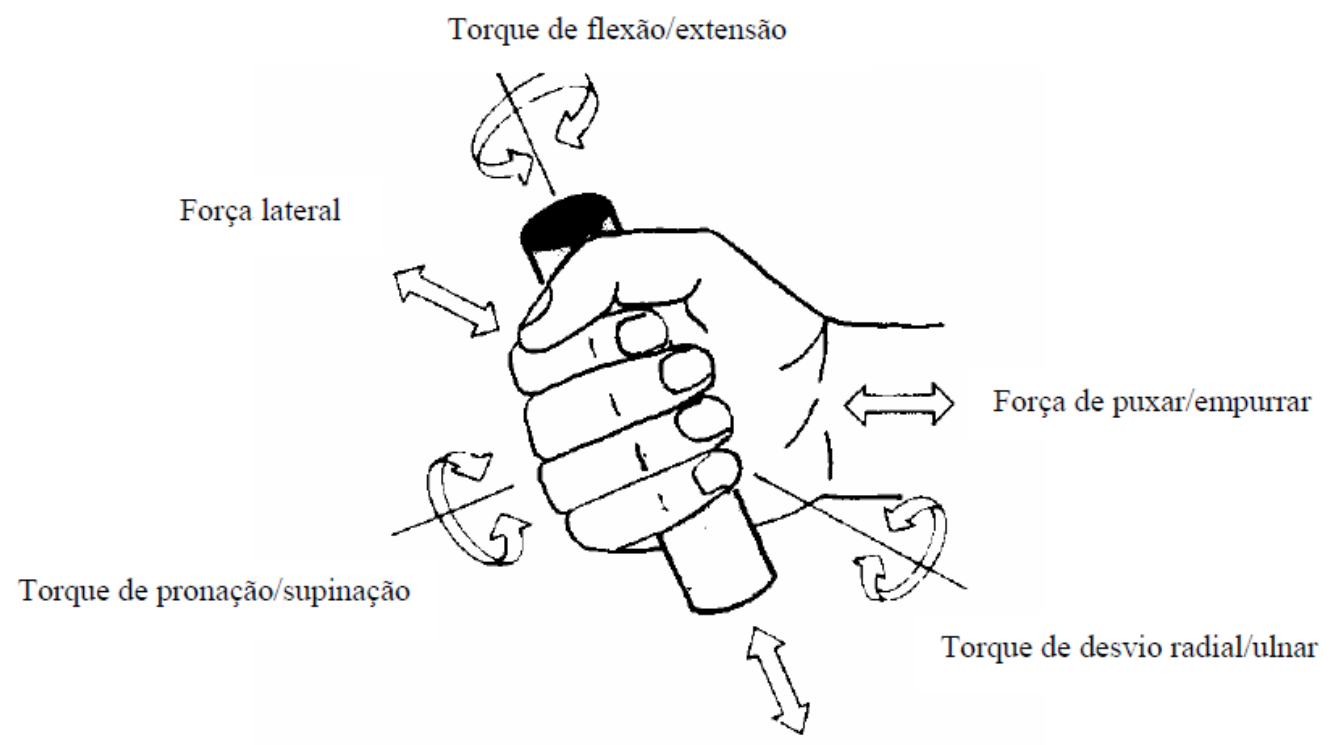

Força de pressão longitudinal

Figura 6. Pega do tipo força; e todas as forças e torques que podem ser aplicados para o manuseio com mão neste tipo de pega (DRURY, 1984 apud CUSHMAN \& ROSENBERG, 1991, p. 51). 
Já para uma avaliação da usabilidade destes produtos, a pesquisa se baseará nas dez heurísticas de NIELSEN (1994), que podem ser traduzidas para este produto da seguinte maneira (Tabela 6):

\begin{tabular}{|c|c|}
\hline $\begin{array}{l}\text { Visibilidade de status do } \\
\text { produto }\end{array}$ & $\begin{array}{l}\text { A faca deve informar constantemente seu estado durante seu manuseio (estados como suja, limpa, } \\
\text { fio amolado, fio cego). }\end{array}$ \\
\hline $\begin{array}{l}\text { Correspondência entre o } \\
\text { produto e o mundo real }\end{array}$ & $\begin{array}{l}\text { O usuário não deve se perguntar se aquele produto é uma faca ou outra ferramenta: uma faca deve } \\
\text { se parecer com uma faca. }\end{array}$ \\
\hline $\begin{array}{l}\text { Liberdade e controle para } \\
\text { o usuário }\end{array}$ & $\begin{array}{l}\text { O usuário deve poder escolher como manusear a faca sem se prejudicar ou se ferir. Mas as } \\
\text { diferentes formas de uso devem estar evidentes no momento de sua escolha. }\end{array}$ \\
\hline Consistência e normas & $\begin{array}{l}\text { Facas não devem ter diferenças em suas formas de uso, mas na aplicação para a qual se adequam. } \\
\text { É preferível que a faca possua um perfil e uma moagem conhecidos. }\end{array}$ \\
\hline Prevenção de erros & $\begin{array}{l}\text { Evitar componentes, formas ou cores que induzam o usuário ao erro. Mas caso não seja possível } \\
\text { evitá-los no design, inclua maneiras de proteger o usuário de acessar tais partes. }\end{array}$ \\
\hline $\begin{array}{l}\text { Reconhecer é melhor que } \\
\text { lembrar }\end{array}$ & $\begin{array}{l}\text { O usuário deve reconhecer a faca e entender como usá-la imediatamente, independentemente de } \\
\text { sua proficiência com o produto. }\end{array}$ \\
\hline $\begin{array}{l}\text { Flexibilidade e eficiência } \\
\text { no uso }\end{array}$ & A faca precisa oferecer segurança e conforto para usuários amadores e profissionais. \\
\hline $\begin{array}{l}\text { Estética e design } \\
\text { minimalista }\end{array}$ & $\begin{array}{l}\text { Evite componentes puramente estéticos na faca: cada componente extra não essencial compete } \\
\text { com outros componentes funcionais, desviando a atenção do usuário. }\end{array}$ \\
\hline $\begin{array}{l}\text { Ajude os usuários a } \\
\text { reconhecer, diagnosticar e } \\
\text { se recuperar de erros }\end{array}$ & $\begin{array}{l}\text { Caso manuseie a faca incorretamente, o usuário precisa identificar facilmente que erro cometeu, } \\
\text { compreender por que errou e como se recuperar do erro (aqui, erros de manuseio. A faca é incapaz } \\
\text { de recuperar o usuário de um dano cometido a si próprio ou a outro indivíduo). }\end{array}$ \\
\hline Ajuda e documentação & $\begin{array}{l}\text { Providencie um manual de uso, com o detalhamento técnico do produto, suas partes, sua } \\
\text { montagem, formas de manutenção e bases de manuseio. }\end{array}$ \\
\hline
\end{tabular}

Tabela 6. Heurísticas de usabilidade para facas táticas (NIELSEN, 1994; tradução e adaptação dos autores).

Nesta pesquisa serão empregados tais parâmetros de avaliação para analisar o desenvolvimento de facas táticas capazes de suprir corretamente as necessidades de seus usuários, pois estarão adequadas às suas aplicações e aos contextos em que são utilizadas. Foi a partir disso que surgiu a necessidade de envolver estes usuários no estudo, para entender sua visão e vivência acerca de tais artefatos.

\section{Testes de Manuseio com Facas Táticas e Simulacros}

$\mathrm{Na}$ academia de artes marciais, ocorreram três sessões de Grupo Focal com especialistas em combate e caça, além de uma aplicação de questionário. Cada um dos encontros teve objetivos específicos, e alcançou dados distintos, mas igualmente importantes aos resultados deste projeto. Houve dois grandes momentos na realização dessas atividades: o que antecede a consciência do usuário quanto ao conhecimento sobre tipos e aplicações das facas em contextos hostis, como combate e caça; e aquele posterior à descoberta de todas essas informações, quando os usuários estão cientes das diversas possibilidades na escolha de seus equipamentos e como idealizam o uso de suas facas, havendo reapropriação dos instrumentos.

Nesse caso, as sessões serviram para mapear as características dos grupos de participantes, especialmente aquelas contextuais, que os fazem necessitar de facas para realizá-las. Também, definir as amostras de testes e conseguir respostas a uma série de perguntas pré-definidas. $\mathrm{O}$ perfil dos participantes e as características das amostras podem ser consultados na Tabela 7.

\begin{tabular}{|l|l|}
\hline Perfil de usuário & Descrição \\
\hline Quanto à faixa etária & Entre 18 e 55 anos. \\
\hline Quanto à educação & Graduação completa. \\
\hline Quanto à ocupação & Profissionais de áreas militares, de resgate ou de segurança (4 concursados, 1 não informou). \\
\hline Quanto ao sexo & Indiferente. \\
\hline Quanto ao endereço & Todos residentes de zonas urbanas. \\
\hline Características das Amostras & Descrição \\
\hline Quanto ao tipo e material & Simulacros de faca tática feitos em madeira. \\
\hline Quanto à tecnologia & Simulacros totalmente analógicos. \\
\hline Quanto à fidelidade & Simulacros com dimensão exata e peso reduzido. \\
\hline
\end{tabular}

Tabela 7. Perfil dos participantes e características das amostras dos simulacros de facas (produção dos autores).

Todos os seis participantes dos Grupos Focais tinham a idade legal mínima para portar armas de fogo e armas brancas, e todos possuíam graduação completa. Eles vinham de profissões diretamente ligadas a

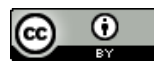


atividades de combate ou de sobrevivência em ambientes hostis, sendo dois oficiais militares, um bombeiro, um policial e uma socorrista. O instrutor também estava ligado a essas profissões, sendo convidado recorrente de sessões de treinamento em combate de forças policiais do Estado de Pernambuco. Os simulacros eram objetos de treino que simulavam o corpo de facas de combate, contudo, seu peso era muito diferente das facas táticas reais, devido ao material de fabricação e à quantidade de componentes (simulacros eram monoblocos, isso é, foram produzidos num único bloco de madeira).

\subsection{Primeira Sessão - Grupo Focal}

No primeiro encontro, foi feita uma apresentação da pesquisa, do pesquisador e da academia. Houve também uma conversa horizontal entre todos os participantes, com a devida identificação das pessoas e suas profissões, o motivo para praticarem artes marciais e porque achavam importante manusear facas corretamente. Neste mesmo dia, discutiu-se sobre os diversos tipos de facas; materiais e processos comuns à fabricação desses produtos; e formas básicas de manuseio das facas em contextos hostis, como ambientes com animais selvagens, matas densas e praias desérticas. Nesse sentido, era importante mapear essas diversas atividades e distinguir quais tarefas eram únicas de cada contexto e quais eram comuns a todos. Para tal, foi utilizada a Teoria da Atividade de LEONTIEV (1978).

Segundo ele, toda atividade pode ser decomposta em três grandes níveis de tarefas, que por sua vez, se integram a outros conjuntos com três grandes níveis. Cada conjunto representa uma atividade, e cada atividade só existe quando um sujeito define um objeto (um foco) em torno de seu esforço (LEONTIEV, 1978; VYGOTSKY, 1978). Para tal, o primeiro nível é da atividade em si, da finalidade do esforço; o segundo nível é o da ação, do esforço comportamental e motor para se alcançar o objetivo; e o terceiro, da operação, dos processos manuais ou técnicos necessários para realizar uma ação.

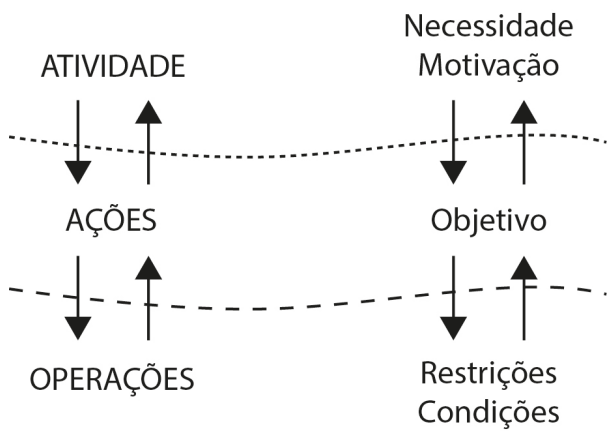

Figura 7. Níveis de uma atividade (SANTOS \& MERKLE, 2009) e Tríade da Atividade (ENGESTRÖM, 1987; 1993).

Conforme ilustrado na Figura 7 acima, os artefatos possuem significados atrelados ao contexto da atividade, no qual funcionam como mediadores - um produto ou signo nada mais é que uma maneira de uma pessoa efetuar uma ação (SANTOS \& MERKLE, 2009). Esse mapa (Figura 8) serviu para categorizar os participantes, os instrumentos e os contextos de uso, permitindo uma visão de como os usuários interagiam comumente com os artefatos estudados, ou seja, quais eram as atividades, as ações e as operações (Tabela 8). 


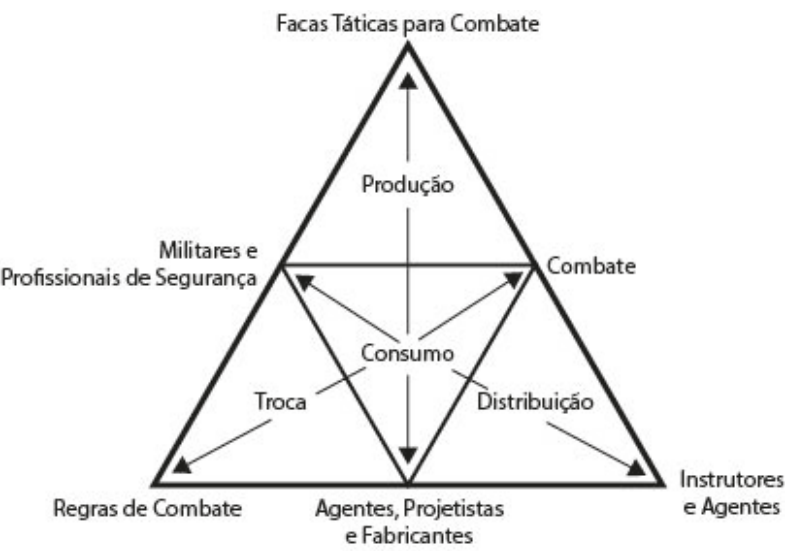

Uso em Ambientes Hostis para o Combate

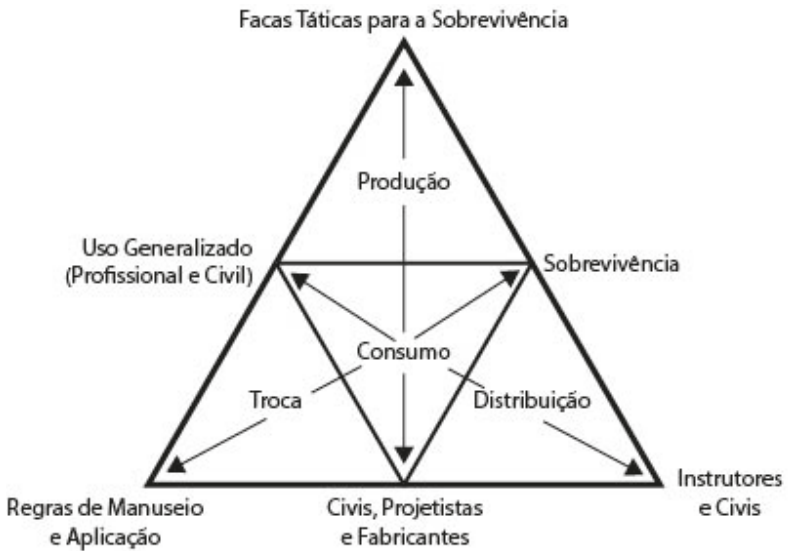

Uso em Ambientes Hostis para Manutençáo da Vida

Figura 8. Tríades das Atividades identificadas com os participantes. Segundo eles, há dois grandes contextos para o uso de facas táticas: o combate e a sobrevivência, sendo o primeiro voltado à luta e o segundo à caça e à coleta de recursos para a manutenção da vida.

\begin{tabular}{|c|c|c|c|}
\hline Atividade & Ações & \multicolumn{2}{|l|}{ Operações } \\
\hline \multirow[t]{4}{*}{ Combate } & Golpe Letal & \multicolumn{2}{|c|}{$\begin{array}{l}\text { - Mirar em zona mortal do corpo inimigo; } \\
\text { - Perfurar zona mortal OU; } \\
\text { - Lacerar zona mortal. }\end{array}$} \\
\hline & Golpe & \multicolumn{2}{|c|}{$\begin{array}{l}\text { - Mirar em qualquer parte do corpo inimigo; } \\
\text { - Perfurar, lacerar ou contundir, com intenção de ferir. }\end{array}$} \\
\hline & Defesa & \multicolumn{2}{|c|}{$\begin{array}{l}\text { - Obstruir golpe do inimigo; } \\
\text { - Quebrar sua ofensiva OU; } \\
\text { - Redirecionar o ataque inimigo. }\end{array}$} \\
\hline & Desarmamento & \multicolumn{2}{|c|}{$\begin{array}{l}\text { - Obstruir golpe do inimigo; } \\
\text { - Retirar a arma do inimigo. } \\
\end{array}$} \\
\hline Atividade & $\begin{array}{l}\text { Micro- } \\
\text { atividades }\end{array}$ & Ações & Operações \\
\hline \multirow[t]{7}{*}{ Sobrevivência } & \multirow[t]{2}{*}{ Caça } & Golpe Letal & $\begin{array}{l}\text { - Mirar em zona mortal do corpo do animal; } \\
\text { - Perfurar zona mortal OU; } \\
\text { - Lacerar zona mortal. }\end{array}$ \\
\hline & & Golpe & $\begin{array}{l}\text { - Mirar em qualquer parte do corpo do animal; } \\
\text { - Perfurar, lacerar ou contundir, com intenção de ferir. }\end{array}$ \\
\hline & \multirow[t]{4}{*}{$\begin{array}{l}\text { Coleta de } \\
\text { Recursos }\end{array}$} & Coletar água & $\begin{array}{l}\text { - Mirar em parte de caule úmido ou cactácea; } \\
\text { - Levantar braço para iniciar arco de corte; } \\
\text { - Efetuar arco de corte de cima para baixo, inclinado; } \\
\text { - Arrancar ripa do corpo do vegetal OU; } \\
\text { - Estropiar caule ou cacto; } \\
\text { - Recolher água com recipiente. }\end{array}$ \\
\hline & & Coletar minerais & $\begin{array}{l}\text { Ao encontrar mineral maleável (e.g. argila): } \\
\text { - Escavar com lâmina para amolecer mineral; } \\
\text { - Desprender quantidade de mineral da fonte; } \\
\text { - Recolher mineral em recipiente. }\end{array}$ \\
\hline & & $\begin{array}{l}\text { Coletar frutas e } \\
\text { leguminosas }\end{array}$ & $\begin{array}{l}\text { - Cortar suporte da fruta (área do caule) OU; } \\
\text { - Escavar raiz da fruta ou leguminosa; } \\
\text { - Cortar raiz da fruta ou leguminosa. }\end{array}$ \\
\hline & & $\begin{array}{l}\text { Coletar ervas } \\
\text { medicinais }\end{array}$ & $\begin{array}{l}\text { - Cortar caule das mudas ou folhas; } \\
\text { - Manter folhas inteiras ou picar com faca. }\end{array}$ \\
\hline & $\begin{array}{l}\text { Tratamento de } \\
\text { Recursos }\end{array}$ & $\begin{array}{l}\text { Cortar e raspar } \\
\text { madeira e mato }\end{array}$ & $\begin{array}{l}\text { - Mirar em parte de caule seco fino (cana ou bambu), cipó ou } \\
\text { arbusto; } \\
\text { - Levantar braço para iniciar arco de corte; } \\
\text { - Efetuar arco de corte de cima para baixo, inclinado; } \\
\text { - Cortar rapidamente com um movimento OU; } \\
\text { - Repetir o movimento de arco até estropiar; } \\
\text { - Apoiar caule no tórax, segurando com uma das mãos; } \\
\text { - Deslizar a faca rapidamente e com força, sobre o caule, levemente } \\
\text { inclinada para penetrar nas camadas superficiais da planta; } \\
\text { - Ao fim do movimento, redirecionar a faca para fora, para arrancar } \\
\text { lascas do caule. }\end{array}$ \\
\hline
\end{tabular}




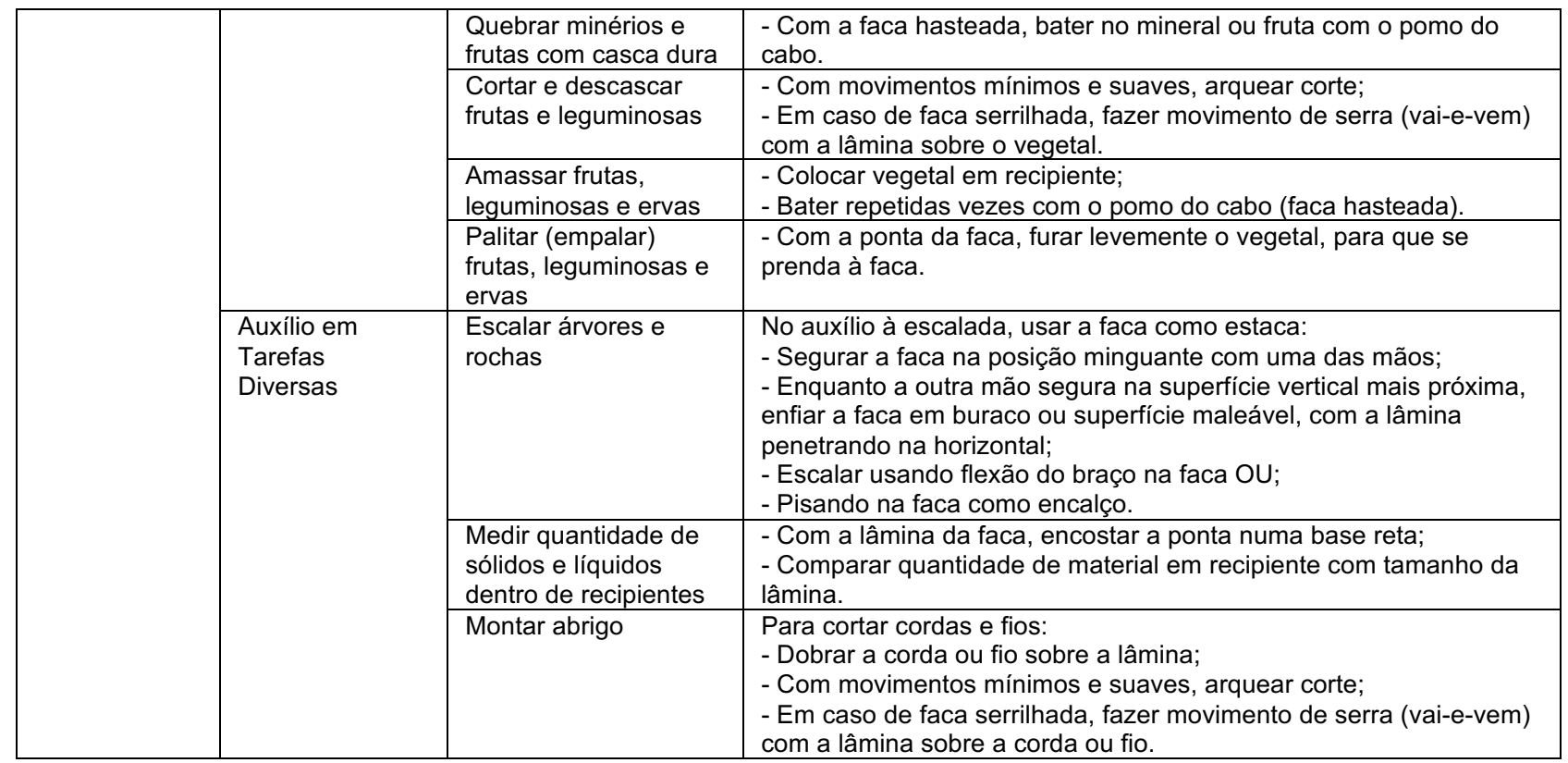

Tabela 8. Duas atividades no uso de facas táticas e suas muitas ações e operações (produção dos autores).

Uma vez que essas duas atividades estavam claras ao grupo, a próxima etapa seria entender que movimentos e posições os usuários executam para conseguir realizar essas operações, as quais são, em sua maioria, atividades musculares. Para isso, foi realizado um segundo encontro.

\subsection{Segunda Sessão - Grupo Focal}

No segundo encontro, foram avaliados os estudantes enquanto manuseavam três simulacros de faca (Figura 9). Nesse momento, foram apresentadas formas comuns de manuseio das facas, modos de segurar o cabo e táticas de combate. Os três simulacros pertenciam à academia e, segundo o instrutor, eram os tipos mais comuns presentes em facas de combate. Dois deles permitiam uma melhor acomodação dos dedos no cabo (cabos um e três), pois possuíam leves arqueamentos. O simulacro 3 tinha um sistema de segurança para os dedos que impedia o deslizamento da faca na mão, já que os dedos ficavam presos na guarda e na extremidade do cabo. Já o simulacro dois era o menos seguro, mas que tinha o melhor equilíbrio no manuseio, além de permitir diversas maneiras de segurá-lo e uma transição facilitada entre essas formas de manuseio, já que todo o corpo do cabo era simétrico. Como esses modelos simétricos visam o equilíbrio, eles são mais indicados para lâminas de fio composto.

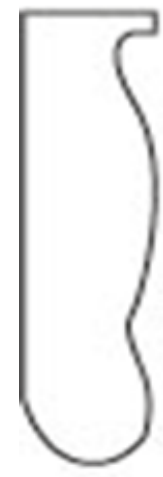

1

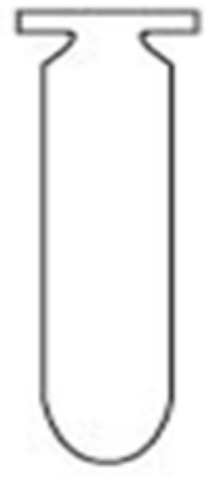

2

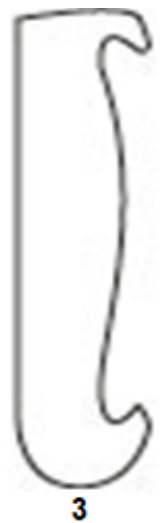

3

Figura 9. Três modelos de simulacros usados no treinamento dos estudantes (produção dos autores). 
Essas percepções se mostravam relevantes, quando vindo dos estudantes, pois faziam com que eles mesmos entendessem melhor como manusear uma faca e para que finalidade. De movimentos de combate até ações civis, como cortar e descascar frutas; pescar e retirar escamas de peixe; caçar e retirar couro e pelos de animais; todas essas ações poderiam melhorar agora que eles compreenderam como escolher ou desenhar uma faca com qualidade ergonômica.

Dois movimentos básicos e duas posições para segurar a faca foram descritos pelos participantes: 1) movimento de arco longitudinal para lacerar, quando a pessoa balança a lâmina em punho, de cima para baixo, de baixo para cima, ou de um lado para o outro, criando uma parábola na ponta da faca, do início até o fim do trajeto; o mesmo movimento, em menor distância percorrida, é usada para descascar frutas e raspar madeira; 2) movimento de impulso para perfurar, quando a pessoa aponta a extremidade da faca para o alvo, puxa o artefato para perto de si e o impulsiona para frente, num movimento retilíneo. Finalmente, uma faca pode ser segurada com a lâmina para cima (hasteada) ou para baixo (minguante). Segundo o instrutor, posições e movimentos, quando unidos, permitem a criação de uma gama diversificada de operações. A equipe chegou à conclusão de que esses movimentos são empregados também com variações de força aplicada e do tamanho ou curvatura do percurso percorrido pela mão.

\subsection{Terceira Sessão - Grupo Focal}

Já no último encontro, os participantes responderam individualmente a um questionário de ergonomia e usabilidade, para entender que tipo de faca mais se adequava ao contexto deles e, mais importante, que características eram essenciais às facas. $\mathrm{O}$ emprego de questionários relativos à ergonomia e à usabilidade (Apêndice A), baseados nas propostas de estudo de CUSHMAN \& ROSENBERG (1991) e de NIELSEN (1994) foram preenchidos por cada um dos avaliados durante o uso de simulacros para treino.

O questionário inicia abordando questões voltadas à ergonomia do objeto, desde o formato da pega (Figura 10) até questões como a segurança que as formas do objeto estudado oferecem ao usuário. Posteriormente, houve questões voltadas à usabilidade, para levantar dados sobre a interação e a compatibilidade das facas com o cotidiano dos usuários. Cada usuário tinha sua própria faca ou manipulava uma faca em seu contexto de trabalho. Essas facas se enquadravam dentro desses mesmos modelos de simulacros, com pequenas variações estéticas ou aditivos funcionais. As questões e resultados mais relevantes estão descritos nas Tabelas 9 e 10 a seguir:

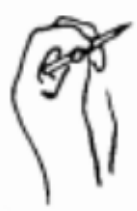

7

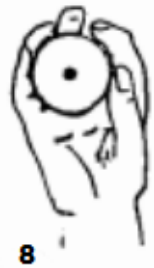

8

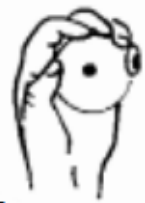

9

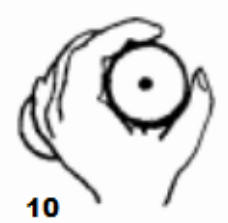

10

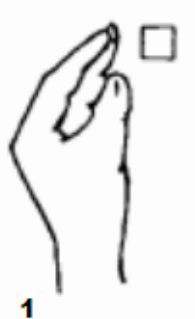

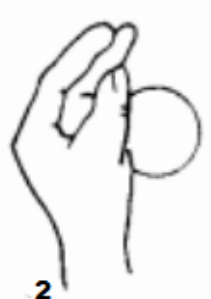

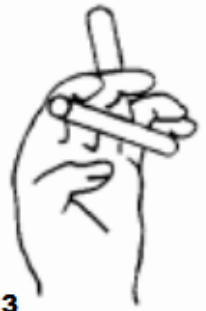

3
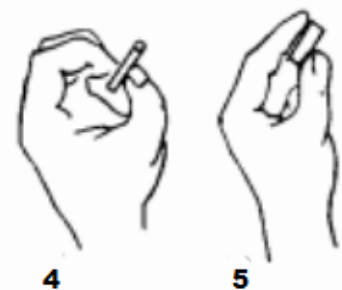

5

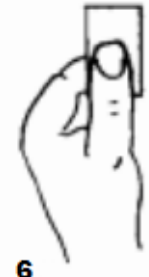

Figura 10. Diferentes tipos de pega para produtos manuais (KROEMER, 1986 apud CUSHMAN \& ROSENBERG, 1991; adaptação dos autores). 


\begin{tabular}{|c|c|c|}
\hline Questão & Incidência & Síntese dos resultados \\
\hline $\begin{array}{l}\text { Qual o grau de adequação dos } \\
\text { modelos de faca que você utiliza } \\
\text { às suas mãos? }\end{array}$ & $\begin{array}{l}1 \text { - Excelente; } \\
2 \text { - Bom; } \\
3 \text { - Regular. }\end{array}$ & $\begin{array}{l}\text { A média dos resultados indicou bons níveis de adequação. } \\
\text { Não se sabe se as respostas dos usuários eram influenciadas } \\
\text { (as facas que conheciam ou interagiam no trabalho eram de } \\
\text { suas marcas favoritas). Do ponto de vista do especialista, } \\
\text { havia muitas falhas ergonômicas quanto ao comprimento e à } \\
\text { largura dos cabos (muito curtos e finos, e pouco anatômicos). }\end{array}$ \\
\hline $\begin{array}{l}\text { Que tipo de pega o cabo de sua } \\
\text { faca permite durante sua } \\
\text { manipulação para que haja o uso } \\
\text { correto (Figura } 7 \text { )? }\end{array}$ & $\begin{array}{l}5 \text { - Pega } 10 \\
5 \text { - Pega } 9 \\
1 \text { - Pega } 3\end{array}$ & $\begin{array}{l}\text { Avaliou-se o relato dos usuários quanto à pega das facas que } \\
\text { usavam em atividades reais. Dentre elas, quatro modelos } \\
\text { diferentes de produto permitiam três tipos de pegas. } \\
\text { Relataram que a pega } 10 \text { (pega de força) era possível em } \\
\text { todos os tipos comuns de faca, e a pega } 9 \text { (incluso palma e } \\
\text { dedo) também, só que nesse caso, a faca não era segurada } \\
\text { para cima - e sim com a lâmina para baixo e o polegar sobre } \\
\text { o pomo. A pega } 3 \text { (gancho) só era possível em uma das facas } \\
\text { de uma participante, que era uma adaga de impulso, usada } \\
\text { para perfurações. }\end{array}$ \\
\hline $\begin{array}{l}\text { O modelo de cabo de sua faca } \\
\text { segue a correta diretriz de } \\
\text { tamanho que é proposta na } \\
\text { pesquisa? E a lâmina? }\end{array}$ & $\begin{array}{l}\text { Nenhum dos } 5 \text { modelos } \\
\text { seguia as propostas de } \\
\text { tamanho. }\end{array}$ & $\begin{array}{l}\text { Os usuários perceberam que todas as cinco facas falharam } \\
\text { nesse quesito, sendo que as lâminas possuíam menos falhas } \\
\text { que os cabos, quase sempre pouco ou demasiadamente } \\
\text { volumosos, dificultando de serem segurados. }\end{array}$ \\
\hline $\begin{array}{l}\text { Você sabe qual o peso total de } \\
\text { sua faca? Acha que ela está } \\
\text { dentro do valor ideal para uso } \\
\text { proposto na pesquisa? }\end{array}$ & $\begin{array}{l}\text { Todas as facas seguiam a } \\
\text { proposta (peso até } 0,4 \mathrm{~kg} \text { ). }\end{array}$ & $\begin{array}{l}\text { Usuários desconheciam o peso de suas facas, mas nenhum } \\
\text { reclamou da sensação de peso que elas provocavam, que era } \\
\text { muito baixo. }\end{array}$ \\
\hline $\begin{array}{l}\text { Sua faca permite ou deveria } \\
\text { permitir qual(is) tipo(s) de } \\
\text { movimento(s) abaixo? }\end{array}$ & $\begin{array}{l}5 \text { - Lacerar; } \\
5 \text { - Perfurar; } \\
3 \text { - Contundir. }\end{array}$ & $\begin{array}{l}\text { Suas facas permitiam o uso formal de quase todos os } \\
\text { movimentos possíveis - laceração, perfuração e contusão - } \\
\text { mas nem todos eram notados pelos usuários antes dos } \\
\text { encontros. }\end{array}$ \\
\hline $\begin{array}{l}\text { Quantos componentes o produto } \\
\text { possui? Você acha que eles são } \\
\text { realmente necessários para o } \\
\text { correto funcionamento de sua } \\
\text { faca? Eles geram poluição visual? }\end{array}$ & $\begin{array}{l}\text { Apenas um participante } \\
\text { soube responder. }\end{array}$ & $\begin{array}{l}\text { Comprovou-se através deste estudo que a maioria das } \\
\text { pessoas, mesmo as que treinam com facas, não têm } \\
\text { conhecimento dos componentes que fazem parte de uma } \\
\text { faca, sendo que apenas uma sabia deles e que sua presença } \\
\text { ou ausência afetava diretamente o uso da faca - este } \\
\text { indivíduo, por sinal, era o instrutor, mas respondeu numa } \\
\text { linguagem pouco técnica, usando termos comuns. }\end{array}$ \\
\hline
\end{tabular}

Tabela 9. Questões ergonômicas mais relevantes das facas dos seis avaliados (produção dos autores).

\begin{tabular}{|l|l|l|}
\hline Questão & Incidência & Síntese dos resultados \\
\hline $\begin{array}{l}\text { Sua faca é consistente com o } \\
\text { conceito geral do que é uma faca? }\end{array}$ & $\begin{array}{l}\text { Todos os participantes } \\
\text { afirmaram que sim. } \\
\begin{array}{l}\text { Ela é semelhante ao modelo } \\
\text { mental do que é uma faca de uso } \\
\text { tático para você? }\end{array}\end{array}$ & $\begin{array}{l}\text { Quatro das cinco facas com as quais relataram suas } \\
\text { experiências de uso, eram semelhantes às mais comuns } \\
\text { encontradas no mercado. Segundo os participantes, mesmo } \\
\text { um leigo conseguiria identificá-las e usá-las. }\end{array}$ \\
\hline $\begin{array}{l}\text { Você acredita que sua faca } \\
\text { poderia ser facilmente usada por } \\
\text { uma pessoa sem treinamento ou } \\
\text { prática? E ela é uma faca } \\
\text { eficiente? }\end{array}$ & $\begin{array}{l}\text { Todos os participantes } \\
\text { afirmaram que sim. }\end{array}$ & $\begin{array}{l}\text { Segundo eles, é importante haver um cuidado e uma } \\
\text { educação do usuário de facas táticas, pois elas não são como } \\
\text { aquelas para uso doméstico, causando muito mais danos. } \\
\text { Mas qualquer pessoa consegue usar uma faca tática, ainda } \\
\text { que não consiga usufruir de todo o potencial da ferramenta. }\end{array}$ \\
\hline $\begin{array}{l}\text { Sua faca possui algum manual de } \\
\text { uso? Se sim ou não, ele é } \\
\text { necessário? }\end{array}$ & $\begin{array}{l}\text { Todos afirmaram que não } \\
\text { tiveram acesso a manuais } \\
\text { (não vieram com o produto). } \\
\text { O que sabiam, aprenderam } \\
\text { no curso de combate. }\end{array}$ & $\begin{array}{l}\text { Nenhum dos modelos possui manual de uso. A utilização } \\
\text { profissional de uma faca e de muitas armas brancas só ocorre } \\
\text { a partir da busca por educação formal. }\end{array}$ \\
\hline
\end{tabular}

Tabela 10. Questões de usabilidade mais relevantes das facas dos seis avaliados (produção dos autores).

Conhecer as possibilidades de uso de uma faca é importante e não deveria depender apenas da educação formal das artes marciais, como o próprio instrutor participante alegara. Por este motivo, ir a campo para descobrir um pouco mais sobre a relação das facas táticas com seus usuários assíduos pôde revelar tópicos importantes para facilitar seu uso correto e consciente por pessoas comuns. Uma vez terminada a última sessão, foi realizado o estudo dos resultados tabulados, a fim de permitir o desenho de diretrizes que objetivassem melhorar a qualidade das facas táticas. A lista de recomendações segue detalhada na Tabela 11 abaixo: 


\begin{tabular}{|c|c|}
\hline $\begin{array}{l}\text { Adequação do formato dos } \\
\text { cabos das facas táticas às } \\
\text { mãos }\end{array}$ & $\begin{array}{l}\text { Os cabos das facas necessitam de maior adequação anatômica, sem limitar a posição e o tipo de } \\
\text { uso de cada modelo. Eles poderiam já possuir o molde de colocação da mão na pega e um } \\
\text { material deformável que se ajustasse à mão de acordo com o tipo de pega. }\end{array}$ \\
\hline $\begin{array}{l}\text { Uso de materiais aderentes } \\
\text { e texturizados }\end{array}$ & $\begin{array}{l}\text { É importante a utilização de materiais que permitam maior aderência das mãos aos cabos e suas } \\
\text { texturas devem ser preferencialmente granulosas ou rugosas, contanto que não incomodem nem } \\
\text { firam a pele do usuário. }\end{array}$ \\
\hline $\begin{array}{l}\text { Manutenção das } \\
\text { capacidades de não-reflexão } \\
\text { da luz }\end{array}$ & $\begin{array}{l}\text { Principalmente em ações de combate e caça, é preciso furtividade. Ao refletir a luz, o usuário fica } \\
\text { exposto, chamando a atenção de pessoas e de animais, apesar de a reflexão facilitar o uso da } \\
\text { faca como sinalizador (quando intencional) para outra pessoa. }\end{array}$ \\
\hline $\begin{array}{l}\text { Facilitação da absorção ou } \\
\text { evaporação do suor e } \\
\text { demais líquidos nos cabos }\end{array}$ & $\begin{array}{l}\text { Quando a mão sua ou se molha, desliza com mais facilidade. Durante um combate ou caçada, se } \\
\text { a mão do usuário fica suja de sangue o mesmo problema acontecerá. Pensando nisso, é } \\
\text { necessário um material que impeça o acúmulo de líquidos em sua superfície, seja pela absorção, } \\
\text { pela evaporação ou pelo escoamento. }\end{array}$ \\
\hline $\begin{array}{l}\text { Permanência de } \\
\text { componentes de proteção } \\
\text { nos cabos e nas lâminas }\end{array}$ & $\begin{array}{l}\text { É importante manter os componentes de segurança da faca (bainha, guarda no cabo, ricasso). } \\
\text { Contudo, esses componentes não devem impedir a mudança de posição de pega ou a } \\
\text { movimentação de dano das facas. }\end{array}$ \\
\hline $\begin{array}{l}\text { Definição de kit essencial de } \\
\text { modelos }\end{array}$ & $\begin{array}{l}\text { Não existe perfil e moagem de faca adequada a todo tipo de corte. Assim, as facas utilizadas por } \\
\text { profissionais devem ser decididas de acordo com o tipo de atividades primárias e secundárias a } \\
\text { que se destinam. }\end{array}$ \\
\hline $\begin{array}{l}\text { Preferência por cores } \\
\text { neutras ou padrões de } \\
\text { camuflagem }\end{array}$ & $\begin{array}{l}\text { As cores neutras tornam as facas mais sérias. Ainda assim, deve-se ter cuidado para que as } \\
\text { cores não impeçam a identificação das partes de uma faca. Algumas cores podem servir de } \\
\text { camuflagem para o artefato, permitindo que ele seja ocultado em diversos ambientes. }\end{array}$ \\
\hline $\begin{array}{l}\text { Transformação dos } \\
\text { componentes em unidades } \\
\text { visíveis, contínuas e } \\
\text { harmônicas }\end{array}$ & $\begin{array}{l}\text { A aprendizagem, o uso e a manutenção das facas precisam ser ensinados sem a necessidade } \\
\text { constante de acessar um manual, ainda que ele seja importante para qualquer produto, atuando } \\
\text { como último recurso de consulta. A faca precisa ter seus componentes distribuídos em unidades } \\
\text { visíveis independentes, mas que conseguem trabalhar como um todo para dar uma boa sensação } \\
\text { de continuação, de que o produto é um só, e não composto por mais de um. Cada grupo de } \\
\text { componentes (cabo e lâmina) também deve ter distinção entre si, sem quebrar esta sensação. }\end{array}$ \\
\hline
\end{tabular}

Tabela 11. Lista de recomendações para o design de facas táticas de combate e de caça (produção dos autores).

Essas melhorias tinham como principal mote aumentar as qualidades ergonômicas, de usabilidade e, como consequência, de Design (estética e adoção dos produtos). Apesar deste projeto não se aprofundar nas questões emocionais, isso é, nos motivos que levam os usuários a comprar determinados perfis de faca; ele resolve, numa primeira investigação, questões práticas muito importantes, relacionadas ao desempenho desses produtos de acordo com a maneira com que são usados.

\section{Conclusões}

Neste projeto foi realizada uma pesquisa sobre a ergonomia e a usabilidade de facas de uso tático, tendo em vista a análise da qualidade dos modelos a partir de requisitos de design para sua melhor, haja vista que os atuais modelos disponíveis não suprem formalmente as necessidades de seus usuários. Para isso, investigouse o conceito básico de uma arma branca e em que posição se encontram as facas nessa classificação; um pouco da influência histórica do uso de armas brancas no momento atual da indústria militar; e como, de um ponto de vista produtivo, a ergonomia e a usabilidade poderiam se posicionar para a criação e a análise de facas táticas.

Dessa forma, foram realizadas incursões com usuários treinados no manuseio profissional de facas e armas brancas, para se entender os riscos que as facas representam, através de três sessões de Grupo Focado, da utilização de Protocolo Pensar Alto e da aplicação de questionário. Com os resultados obtidos de todo esse trajeto, foi desenvolvida uma lista de recomendações para a ergonomia e usabilidade de facas táticas, na tentativa de facilitar o projeto e a análise desses produtos com mais qualidade.

\subsection{Ameaças à Validade dos Procedimentos}

Durante o decorrer da pesquisa, alguns obstáculos tornaram o acesso à informação difícil, já que não há muitos dados acerca da ergonomia e da usabilidade de facas táticas no meio acadêmico, apesar de algumas pesquisas direcionadas aos cabos de ferramentas manuais já terem bastante relevância: muitos compêndios e enciclopédias (produções não-científicas) trazem muitos dados sobre a história, a evolução, a tipologia e a 
produção de armas brancas e das facas. Muitos documentos são particulares das empresas fabricantes, e estão em processo de sigilo industrial ou militar. A informação de mais fácil acesso foi de teor histórico e artesanal.

Além disso, grande parte do que se sabe sobre as características das facas é de natureza empírica, conhecimentos informais passados de geração em geração pelos produtores e artesãos e, mesmo com a atual produção escrita, muito dela não foi cientificamente estudada e comprovada, mas tomou um outro caminho: sua aceitação se deu por meio da tentativa e erro, o que levava seus criadores a tentarem novas formas mais eficientes e letais. Muitos desses conhecimentos estão minimamente relatados por instituições de grande porte e renome industrial, como a KA-BAR Knives Inc. (KA-BAR, 2020) ou a Cold Steel Inc. (Cold Steel, 2020). Apesar da facilidade de inserção do Design enquanto campo de estudo nessas empresas, que têm facas consideradas de alta performance, há certa disparidade entre o que este Design é apto a fazer e o papel que ele realmente desempenha dentro do espaço fabril para transformação científica dos dados.

\subsection{Futuros Trabalhos}

Recomenda-se, a partir dos resultados obtidos e do atual panorama industrial de equipamentos especializados, uma investigação mais profunda para a formalização dos conhecimentos sobre o processo produtivo das facas militares, desde as características estéticas de tais produtos até suas metodologias de design e avaliação, para comprovar estas e outras diretrizes de ergonomia e de usabilidade, buscando um design mais centrado no usuário. Também é importante testar outros materiais nos diversos componentes das facas, a fim de se entender ainda mais a reação deles nos produtos em seu ambiente de utilização, alcançando formas alternativas de produção e de manutenção das qualidades de uma faca.

A abertura dessa pesquisa a temas relativos à Biomimética (BROECK, 1989) aplicada aos equipamentos militares e de segurança, também poderá aproximar os artefatos de uma estética mais orgânica e natural. Também poderá ocorrer a realização desse e de outros procedimentos em demais ferramentas utilizadas para propósitos militares e desportivos, reavaliando toda a estrutura e conceituação formal de seus projetos. Isso permitiria o aumento da demanda por trabalhos de Design, de Ergonomia e de Usabilidade nas indústrias militar, aeroespacial, de segurança, naval e de materiais, através do interesse de novos pesquisadores pelos temas.

\section{Referências Bibliográficas}

A Anatomia da Faca. Arma Branca, 2009. Disponível em: http://armabranca.com/blog/2009/10/16/aanatomia-da-faca/. Acesso em: 18 out. 2020.

BROECK, F. V.. O uso de analogias biológicas. Revista Design e Interiores, São Paulo, n. 15, p. 97-100, 1989.

Cold Steel History. Cold Steel, 2020. Disponível em: https://www.coldsteel.com/coldsteel_history. Acesso em: 4 set. 2020.

CUSHMAN, W. H.; ROSENBERG, D. J.. Human Factors in Product Design. Amsterdam: Elsevier, 1991.

DORLING KINDERSLEY. Armas: uma história visual de armas e armaduras / tradução Tina Jeronymo. 2 ed. São Paulo: Editora Lafonte, 2012.

ENGESTRÖM, Y.. Learning by Expanding: An Activity-Theoretical Approach to Developmental Research. Helsinki, Orienta-Konsultit, 1987. 
ENGESTRÖM, Y.. Developmental Studies of Work as a Testbench of Activity Theory: The case of primary care medical practice. In Understanding Practice. Editado por Seth Chaiklin e Jean Lave. Cambridge University Press, p 64-103, 1993.

JORDAN, P. W.. An Introduction to Usability. 1 ed. Philadelphia: Taylor \& Francis Ltd., 2002.

KA-BAR International. KA-BAR, 2020. Disponível em: https://www.kabar.com/international.html. Acesso em: 4 set. 2020.

Knife Blade Profiles and Uses. Lansky Sharpeners, 2013. Disponível em:

http://lansky.com/index.php/blog/knife-blade-profiles-and-uses/\#.VjBUOLerS70. Acesso em: 29 ago. 2020.

Knife Edge Grind Types. Z Knives, 2005. Disponível em:

http://zknives.com/knives/articles/knifeedgetypes.shtml. Acesso em: 25 out. 2020.

LEONT'EV, A. N.. Activity, Consciousness, and Personality. Prentice Hall, Englewood Cliff, New Jersey, 1978.

MARTIN, B.; HANINGTON, B.. Universal Methods of Design: 100 Ways to Research Complex Problems, Develop Innovative Ideas, and Design Effective Solutions. 1 ed. Massachusetts: Rockport Publishers, 2012.

NIELSEN, J.. 10 Heuristics for User Interface Design. NN/g, 1994. Disponível em: https://www.nngroup.com/articles/ten-usability-heuristics/; e https://en.wikipedia.org/wiki/Blade\#/media/File:Knife_blades_C_series.svg. Acesso em: 4 set. 2020.

PIMENTA, W.. Os Sete Tipos de Armas Brancas, 2011. Disponível em: https://commons.wikimedia.org/wiki/User:Waldir. Acesso em: 4 set. 2020.

SANTOS, M. R.; MERKLE, L. E.. Design em Contradição: Explorando a Teoria da Atividade no entendimento do Design de Produtos. Paraná: CEFETPR, 2009.

VYGOTYSK, L. S.. Mind in society: The development of higher psychological processes. Cambridge: Harvard University Press, 1978.

WARLOEG. Blade styles with typical edges shown as dark grey, 2013. Disponível em: https://en.wikipedia.org/wiki/Blade\#/media/File:Knife_blades_S_series.svg. Acesso em: 4 set. 2020. 
Apêndices

\section{FORMULÁRIO DE AVALIAÇÃO ERGONÔMICA E DE USABILIDADE DE FACAS TÁTICAS PARA USO MILITAR}

Dois questionários transformados num único para avaliação ergonômica e de usabilidade de facas táticas e simulacros de treino. Este formulário foi aplicado nos estudantes e seu instrutor de artes marciais voltadas ao combate com facas.

(para preenchimento pelo avaliado)

I. Qual o tipo geométrico do cabo de sua faca?

$\square$ Cilíndrico

$\square$ Tetraédrico

$\square$ Anatômico

II. E qual o grau de adequação dos modelos de faca que você utiliza às suas mãos?

Péssimo - impossivel realizar o encaixe adequado às mãos, prejudicando o uso (correto) do produto e havendo bastante desconforto.

$\square$ Ruim - há certa dificuldade para realizar o correto encaixe nas mãos, gerando desconforto no manuseio.

Regular - não há dificuldade para segurar o cabo, mas ainda há desconforto.

Bom - há precisão no encaixe, gerando conforto. $O$ uso prolongado não gera desconforto, mas poderia haver mais zonas de contato com a superficie das mãos.

Excelente - há um encaixe perfeito nas mãos, conferindo conforto e facilidade para a realização prolongada de todos os movimentos.

III. Que tipo de pega o cabo de sua faca permite que aconteça durante sua manipulação para que haja o uso correto?
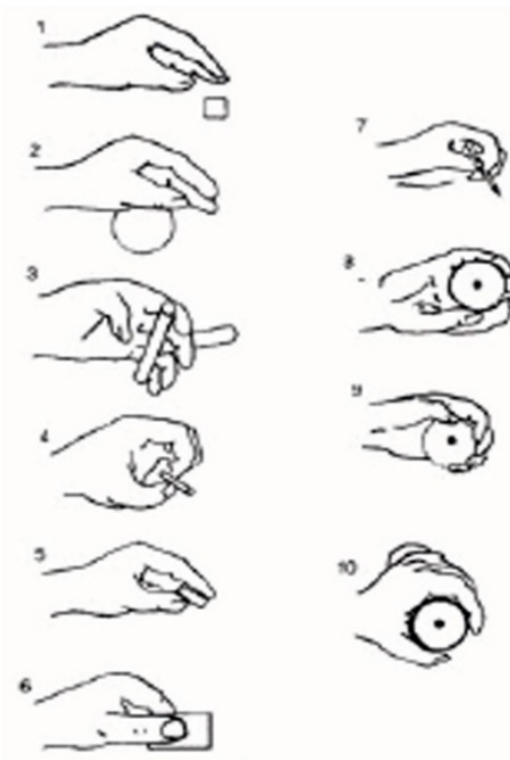

Pega 01 - Toque dos dedos

$\square$ Pega 02 - Toque da palma

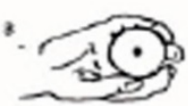

Pega 03 - Pega gancho

$\square$ Pega 04 - Pega de extremidade

$\square$ Pega 05 - Pega de pressão

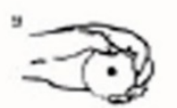

Pega 06 - Pega lateral

Pega 07 - Pega de escrever

Pega 08 - Pega de disco

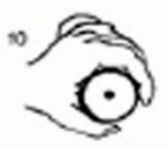

Pega 09 - Incluso palma e dedo

Pega 10 - Pega de força 
IV. Que áreas de contato da mão se fazem mais presentes ao segurar o cabo?

V. O modelo de cabo de sua faca segue a correta diretriz de tamanho que é proposta na pesquisa? E a lâmina?

VI. Você sabe qual o peso total de sua faca? Acha que ela está dentro do valor ideal para uso proposto na pesquisa?

VII. Sua faca permite ou deveria permitir qual(is) tipo(s) de movimento(s) abaixo?

Movimento de corte

$\square$ Movimento de perfuração

$\square$ Movimento de contusão

VIII. Há concisão na escolha de cores e texturas em sua faca? Que tipo(s) de cores, texturas e efeitos abaixo podemos encontrar nela? Como o conjunto destes itens afeta o desempenho dela em uso?

$\square$ Cores neutras $\quad \square$ Efeito liso

$\square$ Cores vividas $\square$ Efeito áspero

$\square$ Cores frias $\quad \square$ Efeito brilhoso

$\square$ Outras cores: $\square$ Efeito fosco

$\square$ Textura metálica $\square$ Outro efeito:

$\square$ Textura amadeirada

Textura emborrachada

$\square$ Textura plastificada

$\square$ Outra textura:

IX. Há firmeza ao se segurar sua faca?

X. Quantos componentes o produto possui? Você acha que eles são realmente necessários para o correto funcionamento de sua faca? Eles geram poluição visual?

XI. Qual o nivel de resistência de sua faca?

$\square$ Baixo

$\square$ Regular

$\square$ Alto

XII. Sua faca Ihe fornece o feedback necessário para sua compreensão de que ela está funcionando corretamente? Que tipo(s) de retorno informacional dentre os dispostos abaixo ela lhe fornece? 


$\begin{array}{ll}\square \text { Visual } & \square \text { Gustativo } \\ \square \text { Táctil } & \square \text { Olfativo } \\ \square \text { Auditivo } & \end{array}$

XIII. Sua faca é compativel com sua realidade? Ela Ihe aparece de forma lógica e de acordo com suas definiçőes de uma boa faca para uso tático?

XIV. Ela Ihe permite o total controle sobre ela? E lhe permite corrigir as próprias açōes caso execute alguma de modo errado?

$X V$. Sua faca é consistente com o conceito geral do que é uma faca? Ela é semelhante ao modelo mental do que é uma faca de uso tático para você?

XVI. O design de sua faca lhe previne manuseá-la de maneira errada? Caso seja usada incorretamente, ela Ihe informa sobre esse erro? Se sim, de que forma?

XVII. Você precisa apelar para seus modelos mentais de uso para manusear a faca corretamente ou você percebe imediatamente como utilizá-la? Ela se deixa identificar como faca e com deve ser utilizada facilmente?

XVIII. Você acredita que sua faca poderia ser facilmente usada por uma pessoa sem treinamento ou prática? E ela é uma faca eficiente?

XIX. Ela possui informações desnecessárias para um uso eficiente? Como ela poderia ser mais simples sem perder eficiência?

XX. Sua faca Ihe providencia um fácil diagnóstico de problemas no manuseio (se a pega está errada, se os movimentos não estão precisos o suficiente, se o material onde ela está entrando em contato não é adequado ao da lâmina, entre outros)?

XXI. Ela possui algum manual de uso? Se sim ou não, ele é necessário para o uso correto? 